\title{
VIITTOMAKIELET HYBRIDISYSTEEMEINÄ - HÄMÄRÄRAJAISUUS JA EPÄKONVENTIONAALISUUS OSANA VIITTOMAKIELTEN RAKENNETTA
}

\author{
Tommi Jantunen, Jyväskylän yliopisto, kieli- ja \\ viestintätieteiden laitos
}

\begin{abstract}
Tässä artikkelissa tarkastellaan hämärärajaisuutta ja epäkonventionaalisuutta osana joitakin kaikista viittomakielistä löydettyjä yksiköitä ja rakenteita ja niiden käyttöä. Täsmällisemmin artikkelin fokuksessa ovat tietyt muodoltaan ja merkitykseltään tilanteisesti muuntuvat viittomat (erityisesti niin kutsutut osittain leksikaaliset viittomat) sekä eräänlainen vaihteleva-asteinen näytteleminen (niin kutsuttu konstruoitu toiminta), jota viittojat käyttävät tuottamiensa syntaktisten rakenteiden osana ja niiden sijaan. Käytännössä artikkeli esittelee näkemyksen, jonka mukaan molemmissa tarkastelun kohteena olevissa ilmiöissä on kyse samasta asiasta eli kielen diskreettien ja konventionaalisten ominaisuuksien sekoittumisesta hybridiluonteisesti kieleen kuuluvien hämärärajaisten ja epäkonventionaalisten ominaisuuksien kanssa. Artikkeli pohtii lyhyesti myös puhuttujen kielten luonnetta hybridisysteemeinä.
\end{abstract}

Avainsanat: ele, epäkonventionaalisuus, hämärärajaisuus, kielisysteemi, suomalainen viittomakieli, viittomakielet

\section{JOHDANTO}

Kun kielitieteilijät alkoivat tarkastella viittomakieliä 1900-luvun jälkimmäisellä puoliskolla luonnollisina kielinä, painottui tutkimuksessa pitkään tarve osoittaa viittomakielten olevan kategorioiltaan suhteellisen tarkkarajaisia - diskreettejä - ja käytöltään vahvasti normitettuja - konventionaalisia rakennesysteemejä, jollaisina puhuttujakin

Kirjoittajan yhteystiedot:

Tommi Jantunen

Kieli- ja viestintätieteiden laitos

PL 35 (F), 40014 Jyväskylän yliopisto

tommi.j.jantunen@jyu.fi kieliä on usein pidetty. Yli puolivuosisatainen viittomakielen tutkimus on kuitenkin jatkuvasti tuottanut evidenssiä, jonka perusteella monet tutkijat ovat alkaneet tulkita viittomakielten kategorioiden ja käytön olevan monilta osin myös vahvasti hämärärajaista ja epäkonventionaalista (esim. Ferrara \& Johnson, 2014; Jantunen, 2015, 2017a; Liddell, 2003). Viime aikoina tästä tulkinnasta on juontunut myös yleisempi ajattelutapa, jossa kieli nähdään eräänlaisena diskreettien ja konventionaalisten ominaisuuksien sekä hämärärajaisten ja epäkonventionaalisten ominaisuuksien jatkumolle sijoittuvana seka- eli hybridisysteeminä (esim. Jantunen, 2017a; Johnston \& Ferrara, 2012), ja tämä käsitys 
on vallannut enenevästi alaa myös puhutun kielen tutkimuksessa (esim. Dingemanse \& Akita, 2016; Enfield, 2009; Floyd, 2016). ${ }^{1}$

Käsillä oleva artikkeli tarkastelee hämärärajaisuutta ja epäkonventionaalisuutta osana joitakin kaikista viittomakielistä löydettyjä yksiköitä ja rakenteita ja niiden käyttöä. Täsmällisemmin artikkelin fokuksessa ovat tietyt muodoltaan ja merkitykseltään tilanteisesti muuntuvat viittomat - erityisesti niin kutsutut osittain leksikaaliset viittomat (esim. Jantunen, 2010; Johnston \& Ferrara, 2012; Liddell, 2003) - sekä eräänlainen vaihteleva-asteinen näytteleminen - niin kutsuttu konstruoitu toiminta (esim. Cormier, Smith \& Sevcikova Sehyr, 2015; Hodge \& Ferrara, 2013; Jantunen, 2017a) - jota viittojat käyttävät tuottamiensa syntaktisten rakenteiden osana ja niiden sijaan. Käytännössä artikkeli esittelee näkemystä, jonka mukaan molemmissa tarkastelun kohteena olevissa ilmiöissä on kyse samasta asiasta eli kielen diskreettien ja konventionaalisten ominaisuuksien sekoittumisesta kieleen kuuluvien hämärärajaisten ja epäkonventionaalisten ominaisuuksien kanssa (ja päinvastoin). Kaikki esitetyt tulkinnat pohjaavat kognitiivis-kommunikatiivisen viittomakielentutkimuksen viitekehyksessä (esim. Schembri \& Johnston, 2017; Wilcox \& Xavier, 2013) tuotettuun uusimpaan tutkimustietoon. Esimerkkitasolla artikkeli hyödyntää paitsi Suomalaisen viittomakielen perussanakirjan (1998) materiaalia, myös ainesta, joka on poimittu tekeillä olevasta laajasta suomalaista viittomakieltä sisältävästä videokorpuksesta (erityisesti Jantunen, Pippuri, Wainio, Puupponen \& Laaksonen, 2016; yleisemmin ks. Salonen, Takkinen, Puuppo-

1 Tämän artikkelin otsikossakin käytetty termi $h y$ bridisysteemi pohjaa Floydiin (2016), joka puhuu puhuttujen kielten kieliopista modaalisesti hybridinä oliona (ks. luku 4). Termin tässä artikkelissa korostamani "unimodaali" (eli ainoastaan kielen visuaalis-gesturaaliseen kanavaan liittyvä) tulkinta on kuitenkin omani. nen, Pippuri \& Nieminen, 2016) ja muusta viimeaikaisesta tutkimusmateriaalista.

Artikkelin keskiössä olevat hämärärajaisuus (jopa kategorioiden puute) ja (kaikenlainen käytön) epäkonventionaalisuus on perinteisesti nähty eleitä, ja johdannaisesti eleellisyyttä, määrittävinä piirteinä (esim. Kendon, 2004, 2008; McNeil, 1992, 2000). Hämärärajaisuuden ja epäkonventionaalisuuden määritelmällinen yhteys eleeseen (johdannaisineen) on lähtökohta myös tälle artikkelille, mutta käsitettä ele ei tekstissä kuitenkaan aktiivisesti käytetä. Ratkaisu johtuu ennen kaikkea elekäsitteen valtavirtamääritelmästä, joka samastaa eleet ensisijaisesti käsien toiminnaksi (ks. Kendon, 2008). Viittomakielissä (ja hieman rajatummin myös puhutuissa kielissä) käsien toiminta voi kuitenkin olla hyvin kategorista ja konventionaalista (so. ei suoraan elettä tai eikä eleellistä), mikä käy ilmi varsin selkeästi tämänkin artikkelin sisällöstä. Toisaalta viittomakielissä (kuten myös puhutuissa kielissä) hämärärajaiset ja epäkonventionaaliset ominaisuudet liittyvät myös muiden artikulaattoreiden (esim. keho, pää, kasvot) kuin käsien toimintaan (so. ele ja eleisyys voi olla myös ei-manuaalista) - käsillä oleva artikkeli tuo ilmi myös tämän seikan. Jos tekstissä halutaan viitata valtavirtamääritelmän mukaiseen eleeseen, käsitettä ele tietenkin käytetään.

Korostettakoon, että vaikka hämärärajaisuuden ja epäkonventionaalisuuden (ja vastaavasti diskreettisyyden ja konventionaalisuuden) käsitteet ovat toisilleen läheisiä ja toinen usein implikoi toista, ne sijoittuvat ontologisesti eri tasoille. Hämärärajaisuus (yhdessä diskreettisyyden kanssa) liittyy kategorioihin ja niiden rajoihin (vrt. perheyhtäläisyys ja prototyyppiteoria), ja se tulkitaan tässä tekstissä lähtökohtaisesti yksilön kognitiivisella tasolla vaikuttavaksi ilmiöksi. Epäkonventionaalisuus (yhdessä konventionaalisuuden kanssa) liittyy puolestaan kielen käyttöön, ja se tulkitaan tekstissä lähtökohtai- 
sesti sosiaalisen tason ilmiöksi. Käytännössä tulkinnoista seuraa, että kielellisen kategorian raja voi olla (ainakin teoreettisesti) hämärärajainen, mutta käyttö konventionaalista; tai käyttö epäkonventionaalista, mutta kategoriat diskreettejä. Systemaattista erottelua eri vaihtoehtojen välillä ei tekstissä kuitenkaan tehdä.

\section{HÄMÄRÄRAJAISUUS JA EPÄKONVENTIONAALISUUS OSANA VIITTOMIEN RAKENNETTA}

Kognitiivis-kommunikatiiviseen viitekehykseen sidotussa viittomakielentutkimuksessa viittomat - käytännössä käsillä tuotetut muodon ja merkityksen yhdistelmät - on tavattu jakaa kolmeen prototyyppiluokkaan: täysin leksikaalisiin viittomiin, osittain leksikaalisiin viittomiin ja ei-leksikaalisiin viittomiin (esim. Johnston \& Ferrara, 2012). Näistä leksikaaliset viittomat ovat sellaisia yksiköitä, joissa muodon ja merkityksen keskinäinen suhde on lähtökohtaisesti hyvin invariantti, ja viittomien kokonaisvaltainen analyysi esimerkiksi morfeemin käsitteen avulla on mielekästä viime kädessä nämä viittomat voidaan tulkita varsin yksiselitteisesti vapaiksi morfeemeiksi (esim. viittomat TILATA ja KOVA, ks. kuvio 1). Kaikista viittomista leksikaaliset viittomat vastaavat parhaiten puhuttujen kielten sanakirjoissa kuvattuja sanoja (sisältösanoja, tekosanoja, funktorisanoja jne.), ja leksikaaliset viittomat muodostavat myös viittomakielten sanakirjojen ytimen (toisinaan jopa koko sanakirjan, joka on kylläkin tällaisessa tapauksessa merkki sanakirjan taustalla olevan työn jonkinlaisesta vääristymisestä). Suomenkielisessä tutkimuksessa leksikaalisista viittomista on toisinaan puhuttu myös "sanamaisina" viittomina (Jantunen, 2010).

Osittain leksikaalisissa viittomissa vain osa viittomien perusrakenteesta (käsimuodosta, orientaatiosta, paikasta, liikkeestä jne.) on leksikaalistunutta ainesta, toisen osan ollessa kontekstin mukaan vaihtelevaa analogista - hämärärajaista ja epäkonventionaalista - ainesta (josta syystä näitä viittomia on suomenkielisessä tutkimuksessa nimitetty kollektiivisesti muun muassa "elekomponentin" sisältäviksi viittomiksi, ks. Jantunen, 2010). Osittain leksikaalistuneet viittomat voidaan jakaa kahteen alaluokkaan, osoittaviin viittomiin (esim. OPETTAA, ks. kuvio 2) ja kuvaileviin viittomiin (esim. PITKULAINEN-KAPEA-ESINE-LIIKKUUKAARESSA-ALAVIISTOON, ks. kuvio

Kuvio 1. Viittomat TILATA (vasemmalla) ja KOVA (oikealla) kuvattuna Suomalaisen viittomakielen perussanakirjassa (1998).
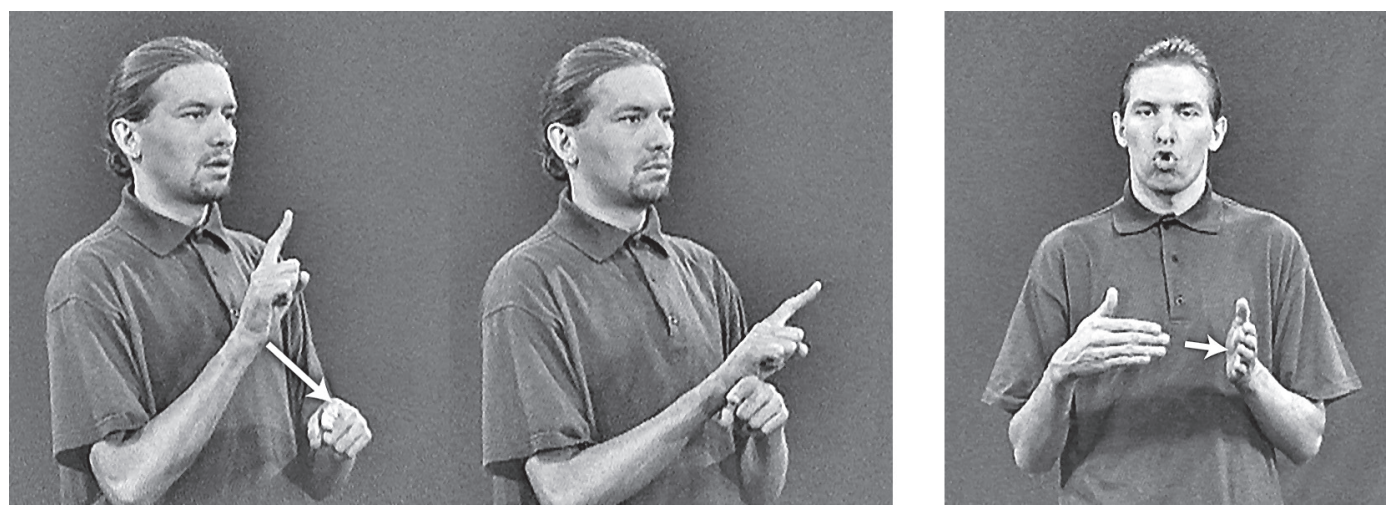
3). Osoittavat viittomat ovat sananmukaisesti viittomia, joiden leksikaalista - diskreettiä ja konventionaalistunutta - merkitystä täydentää osoittamisen eli käytännössä viittomien suuntaamisen avulla luotu ja tulkittu merkitys. Viittomien perusrakenteen näkökulmas- ta osoittavien viittomien leksikaalinen merkitys koodautuu etenkin käsimuodon, paikan ja liikkeen parametreihin. Suuntaamisen avulla tuotettu ja tulkittu merkitys ilmenee puolestaan etenkin orientaatio-parametrin kautta (Liddell, 2003).

Kuvio 2. Kaksi eri tavoin tuotettua esiintymää samasta osittain leksikaalisesta osoittavasta viittomasta OPETTAA. Kun viittoma suunnataan merkityksellisesti, sormenpäät osoittavat aina kohteena olevaa konkreettista osallistujaa tai tämän abstraktia paikkaa. Kuviossa näkyvien viittomaesiintymien tuottoon liittyy myös muuta kehollista toimintaa (konstruoitua toimintaa, ks. luku 3), joka yhdessä viittoman suuntaamisen kanssa implikoi, että tekijän roolissa oleva osallistuja on molemmissa tapauksissa pidempi hahmo kuin kohteen roolissa oleva osallistuja. Kuvat Suomalaisen viittomakielen perussanakirjan (1998) materiaalista.
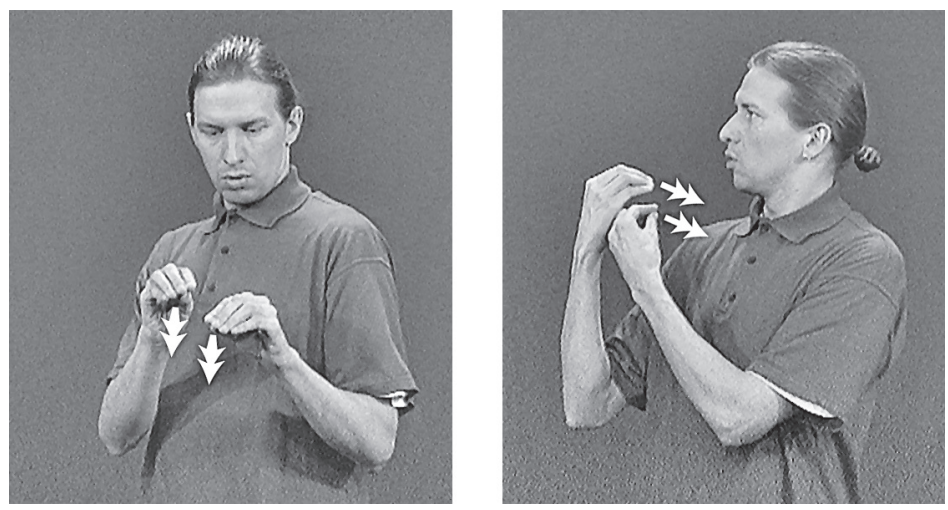

Kuviossa 2 esitetyllä viittomien suuntaamisella tuodaan ilmi eri ominaisuuksia tilanteen osallistujista, tekijästä ja teon kohteesta, ja niiden välisistä suhteista. Se, miten viittoma suunnataan, riippuu ympäröivästä kielellisestä ja kielenulkoisesta kontekstista, esimerkiksi siitä, missä tekijää ja kohdetta edustavat referentit sijaitsevat. Todettakoon kuitenkin, että osoittavilla viittomilla on myös neutraalisti tuotettu perusmuoto, ja että todellisessa kielenkäytössä tämän perusmuodon käyttö voi olla jopa yleisempää kuin suunnattujen, konkreettisesti osoittavien muotojen käyttö (De Beuzeville, Johnston \& Schembri, 2009; Fenlon, Schembri \& Cormier, 2018). Ainakin verbaali-kategoriaan kuuluvien osoittavien viittomien (nk. "tyypin 2 verbaalien", ks.
Jantunen, 2010) suuntaamisessa onkin usein kyse enemmän suuntaamispotentiaalista kuin konkreettisesta suuntaamistoiminnasta (vrt. esim. nominaalikategoriaan kuuluvat etusormella tehtävät osoitukset, joita käytetään esim. merkityksissä 'sinä' ja 'tuo' ja jotka suunnataan aina).

Osittain leksikaalisista viittomista kuvailevat viittomat ovat eniten hämärärajaista ja epäkonventionaalista ainesta sisältäviä yksiköitä (Liddell, 2003). Kuvailevissa viittomissa leksikaalista merkitystä kantaa yleensä vain käsimuoto, joka onkin useissa tutkimuksissa tulkittu merkityksen ja muodon vakioisuuden puolesta klassifikaattorimorfeemiksi (esim. Jantunen, 2008; Takkinen, 2008). Käytännössä uusimman tutkimuksen perus- 
teella näyttää siltä, että morfeemitulkinta olisi näillä kriteereillä tehtävissä kuitenkin vain niin kutsuttujen kokonaiseen kohteeseen viittaavien käsimuotojen osalta, monien muiden käsimuotojen ( $\mathrm{mm}$. hyvin analogisten otekäsimuotojen, kuten käsimuodon, jolla ihmiset pitävät kiinni omenasta tmv., ks. Keränen, 2017) ollessa merkitykseltään liian laajoja tai muodoltaan liian varioivia morfeemianalyysiin. Kuvailevissa viittomissa kuvailu (koon ja muodon kuvailu, liikkeen kuvailu topografisessa tilassa jne.) ilmenee etenkin orientaation, paikan ja liikkeen parametreissa, jotka varioivat analogisesti kuvattavien kohteiden ja tilanteiden orientaatioiden, paikkojen ja liikkeiden kanssa (Liddell, 2003).

Kuvio 3. Osittain leksikaalinen kuvaileva viittoma PITKULAINEN-KAPEA-ESINE. LIIKKUU-KAARESSA-ALAVIISTOON. Dominoivan eli kuvassa oikean käden käsimuoto on tulkittavissa kokonaiseen kohteeseen viittaavaksi klassifikaattorimorfeemiksi, jonka merkitys on 'suorakulmainen objekti'. Muut parametrit vaihtelevat sen mukaan missä asennossa klassifikaattorin koodaama referentti on sekä miten ja missä se liikkuu. Näin ollen viittoman kokonaismerkitys voi olla esimerkiksi 'polkupyörä kulkee mäkeä alas'. Kuva Suomalaisen viittomakielen perussanakirjan (1998) materiaalista.

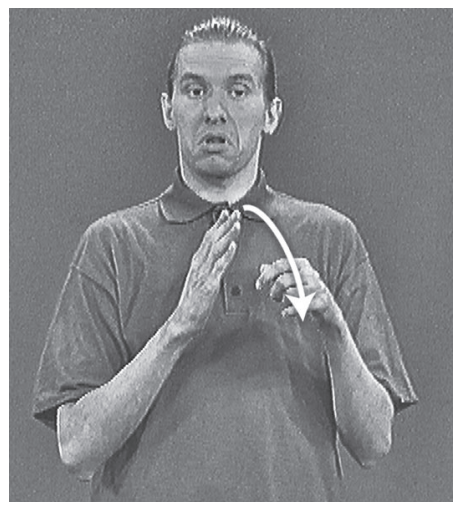

Edellä esitetystä poikkeava, astetta invarientimpi kuvailevien viittomien tyyppi on eksistenssiä topografisessa tilassa ilmaisevat kuvailevat viittomat. Näissä viittomissa myös liike (mahdollisesti kokonaiseen kohteeseen viittaavan käsimuodon kanssa) on tulkittavissa morfeemiksi, sillä se on muodoltaan vakioinen (lyhyt ja suora) ja merkitykseltään yksiselitteinen ('on olemassa') (ks. Takkinen, 2008; eksistentiaali-ilmauksista yleisemmin ks. myös De Weerdt, 2008). Esimerkki eksistenssiä ilmaisevasta kuvailevasta viittomasta on SUORAKAITEEN-MUOTOINEN-ESINE-ON-PAIKASSA. Viittoma tuotetaan siten, että alaspäin suuntautunut kämmenkäsimuoto liikkuu lyhyellä suoralla liikkeellä alaspäin jossakin (tilanteen edellyttämässä) paikassa viittomatilaa. Viittoman merkitys voi olla esimerkiksi 'auto on parkkipaikalla'.

Kuvailevien viittomien merkitys on tavallisesti hyvin laaja ja kattaa usein kokonaisen tilanteen, se ei siis pelkästään esimerkiksi implikoi tilanteen osallistujia tai viittaa pelkästään tilanteessa tapahtuvaan toimintaan. Paljolti tästä syystä nämä viittomat on tulkittu suomalaisessa tutkimuksessa valmiiksi lauseiksi: lausehan kuvaa lähtökohtaisesti kokonaista tilannetta (Jantunen, 2008, 2017b). Ainakin verbaali-kategoriaan kuuluvien, kokonaisen kohteen klassifikaattorikäsimuodon sisältävien kuvailevien viittomien kohdalla lauseanalyysin puolesta voidaan jatkoargumentoida lisäksi siten, että klassifikaattorikäsimuotojen sanotaan olevan lauseen nominaalisia, tilanteen osallistujia koodaavia ydinargumentteja (esim. Van Valin \& LaPolla, 1997). Käytännössä ilmiö vastaa esimerkiksi navahosta ja trotzilista - osin jopa suomesta - löytyvää head-marking -ilmiötä, jossa lauseen pääjäseneen on sulautunut tilanteen osallistujiin viittaavaa ainesta sidonnaisina morfeemeina (Jantunen, 2008; Nichols, 1986).

Ei-leksikaaliset viittomat ovat kaikkein hä- 
märärajaisimpia ja epäkonventionaalisimpia viittomakielten yksiköitä. Käytännössä tähän luokkaan kuuluvat viittomat vastaavat eleitä ja muita viestinnässä käytettäviä yksittäisiä kehon tuotoksia, ja niiden tulkinta vaatii joko kielellisen tai tilanteisen kontekstin kokonaisvaltaista hyödyntämistä (Johnston \& Ferrara, 2012). Suomalaisessa tutkimuksessa tähän luokkaan kuuluvista viittomista on usein puhuttu "pantomiimisina" viittomina ja eleinä (Jantunen, 2010).

Auslanista eli australialaisesta viittomakielestä tehdyn laajan eri tekstilajeja sisältäneen ja yli 100000 koodattua tokeenia eli viittomaedustumaa kattaneen korpustutkimuksen perusteella (Johnston, 2017) 70-prosenttia kielenkäytössä esiintyvistä Auslanin viittomista edustaa jotakin leksikaalista viittomaa. Osittain leksikaalisia viittomia edustaa puolestaan 23-prosenttia viittomista: näistä osoittavaan alatyyppiin kuuluvien edustumien osuus on 12-prosenttia, kuvailevaan alatyyppiin kuuluvien osuus 11-prosenttia. Noin 7-prosenttia Auslanin viittomista edustaa ei-leksikaalisiksi tyypiteltyjä viittomia.

Suomalaisen viittomakielen viittomistoa ei vielä ole mahdollista tutkia yhtä laajan korpuksen avulla kuin Auslanin viittomistoa. Pienemmän (runsaat 4300 tokeenia) ja vain yhdestä tekstilajista (kuvaileva narratiivi) koostuvan otoksen perusteella näyttää kuitenkin siltä, että Auslanista saadut tulokset olisivat yleistettävissä myös suomalaiseen viittomakieleen (Jantunen ym., 2016). Otoksessa leksikaalista ja osittain leksikaalista osoittavaa viittomatyyppiä edustavien viittomien yhteisosuus oli noin 80-prosenttia (vrt. Auslanin 82-prosenttia), ja osittain leksikaalista kuvailevaa ja ei-leksikaalista viittomatyyppiä edustavien osuus noin 20-prosenttia (vrt. Auslanin 18-prosenttia). Tarkempi vertailu Auslanin ja suomalaisen viittomakielen viittomatyyppifrekvenssien välillä ei ole mahdollista aineistonkoodausperiaatteiden erilaisuuden vuoksi.

Viittoman sijoittuminen tiettyyn prototyyppiin ja näihin tyyppeihin perustuva frekvenssien laskenta ei aina ole yksiselitteistä. Yksi haasteellisuutta aiheuttava tekijä tässä on, että monet hyvin ikoniset leksikaaliset ja tietyt osittain leksikaaliset viittomat voivat käytössä varsin helposti de-leksikaalistua. Tämä tarkoittaa, että selkeän konventionaali-

Kuvio 4. Moderni (vasemmalla) ja vanha (oikealla) versio suomalaisen viittomakielen viittomasta ILMA. Modernissa viittomassa käsien liike tuotetaan suhteellisen tiiviinä, vanhassa viittomassa liike on vapaampi ja kuvailevampi. Moderni viittoma voidaan tuottaa myös yksikätisenä, ja on oletettavaa, että vanha viittoma on voitu tuottaa myös kaksikätisenä. Modernin viittoman kuva on peräisin Suomalaisen viittomakielen perussanakirjasta (1998), vanhan 1900-luvun alussa valmistuneesta Hirnin $(1910,1911,1916)$ sanakirjasta.
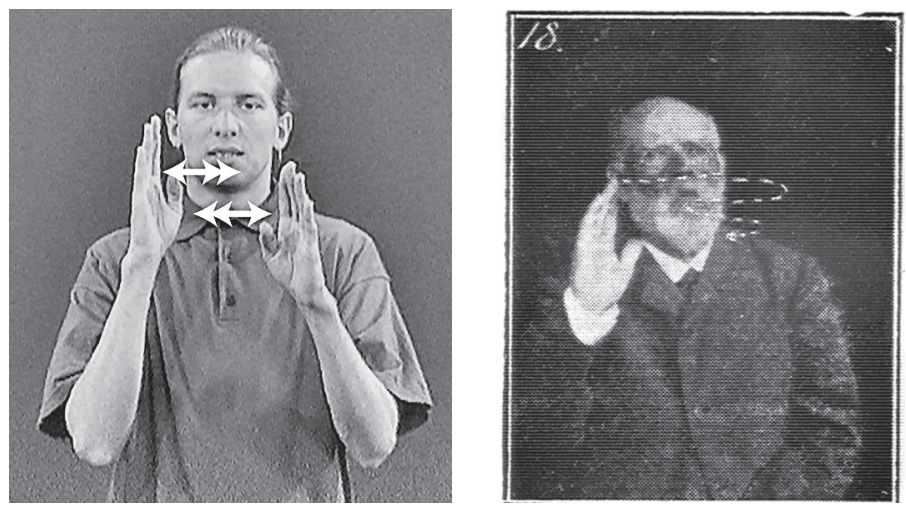
sen muodon ja merkityksen omaava viittoma menettää vakiintuneita piirteitään ja sitä aletaan käyttää hämärärajaisemman ja epäkonventionaalisemman yksikön tavoin (Johnston \& Ferrara, 2012). Käytännössä voidaan puhua siitä, että viittoma de-leksikaalistuessaan palautetaan sen ikonisille, elemäisille juurilleen (Jantunen, 2003; Johnston, 2017), jolloin sen tulkinta jälleen vaatii ympäröivän kontekstin laajamittaisempaa hyödyntämistä. Näin esimerkiksi leksikaalinen viittoma ILMA (sanakirjamerkityksiltään 'ilma' ja 'sää', ks. moderni viittoma kuviossa 4) voidaan tilanteisesti tuottaa alkuperäisen ele-substraattinsa tapaan hyvin vapaasti (ks. vanha viittoma kuviossa 4), jolloin myös sen merkitys yhdistyy enemmän mielikuvaan 'ilman liikkeestä' kuin abstrakteihin käsitteisiin ilma ja sää.

Viittomien tyypittelyä vaikeuttaa myös niin kutsuttu tilannesidonnainen leksikaalistuminen (Johnston \& Ferrara, 2012). Tällaisissa tapauksissa ei-leksikaalisten ja tiettyjen osittain leksikaalisten viittomien muoto ja merkitys kiteytyvät nopeahkosti tiettyyn tilanteen sanelemaan tai tilanteessa neuvoteltuun yhdistelmään. Näiden muodon ja merkityksen pikaparien tuotto automatisoituu muutaman tuottokerran jälkeen yksilötasolla ja muuttuu kyseisessä tilanteessa mukana olevien henki- löiden kesken pikakonventioksi. Toisinaan konventio voi jäädä voimaan myös tilanteen ulkopuolella, jolloin syntyneellä muodon ja merkityksen yhdistelmällä on mahdollisuus jatkaa olemassaoloa varsinaisena uudisviittomana. Yhtä tyypillistä ellei jopa tyypillisempää on kuitenkin se, että tilannesidonnaisen leksikaalistumisen myötä syntyneen viittoman konventio unohdetaan ja viittoma poistuu käytöstä. ${ }^{2}$

Sekä de-leksikaalistumisprosessit että niiden vastaparit eli tilannesidonnaiset leksikaalistumisprosessit osoittavat, että tässä luvussa käsitellyt viittomatyypit ovat määritelmällisesti prototyyppejä ja että ne muodostavat kategorisuuden ja konventionaalisuuden asteille perustuvan jatkumon. Viittomatyyppien sijoittumista tälle jatkumolle on havainnollistettu kuviossa 5 (vrt. Jantunen, 2017a). Hyvin leksikaalistuneet - tarkkarajaiset ja vahvasti konventionaaliset - muoto-merkitys-parit sijoittuvat jatkumon vasempaan päähän. Mitä oikeammalle jatkumolla siirrytään, sitä hämärärajaisemmiksi ja epäkonventionaali-

2 Tilannesidonnaista leksikaalistumista tapahtuu myös sormittamisen yhteydessä eli tilanteissa, joissa tarkoitteisiin halutaan viitata sormiaakkosten jonoilla. Suomalaisen viittomakielen osalta ilmiötä on käsitellyt Tapio (2013).

Kuvio 5. Viittomat kategorisuus-konventionaalisuus-jatkumolla.

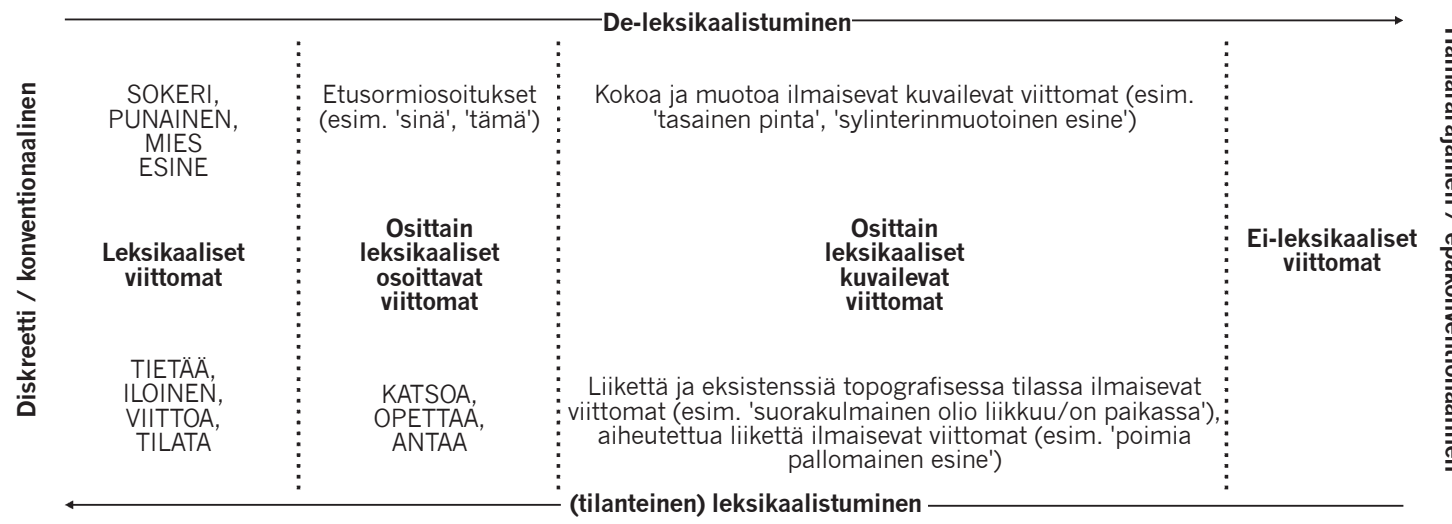


semmiksi muoto-merkitys-parit muuttuvat. Äärimmäisenä oikealla ovat ei-leksikaaliset viittomat, kuten tilanteisesti käytetyt eleet. Kuviossa 5 annetut viittomien glossiesimerkit ja selitykset on sijoiteltu siten, että kuvion yläosassa viitataan pääsanaluokaltaan nominaalisiin viittomiin ja alaosassa verbaalisiin viittomiin (ks. Jantunen, 2010; Rissanen, 1998); käytännössä verbaalisten viittomien sijoittelu noudattaa suomalaisessa tutkimuksessa toisinaan käytettyä jakoa tyypin 1-3 verbaaleihin (Jantunen, 2010). Ei-leksikaalisten viittomien (so. eleiden yms.) kohdalla pääsanaluokkajako ei ole mahdollinen, eikä esimerkkejä ole annettu.

\section{HÄMÄRÄRAJAISUUS JA EPÄKONVENTIONAALISUUS OSANA VIITTOMAKIELTEN SYNTAKSIA}

Myös viittomakielten syntaksi voidaan käsitteellistää kuviossa 5 havainnollistetun kategorisuus-konventionaalisuus-jatkumon avulla (esim. Jantunen, 2017a; Vermeerbergen, 2006). Tällöin jatkumon ääripäistä voidaan puhua vakiintuneena syntaksina ja vapaana syntaksina. Vakiintunut syntaksi perustuu diskreeteille kategorioille ja vahvoille konventioille: sen prototyyppinen lause muodostuu leksikaalisen predikaatin ympärille ( $j a$ koostuu muutenkin leksikaalisista viittomista), on rakenteellisesti kaikin puolin täydellinen (so. ei ole omissioilmiöiden kohde) ja lisäksi noudattaa säännönmukaista viittomajärjestystä (suomalaisen viittomakielen viittomajärjestyksestä ks. Jantunen, 2017b). Vapaa syntaksi perustuu puolestaan hämärärajaisille kategorioille ja epäkonventionaalisuudelle. Prototyyppinen vapaan syntaksin lause rakentuu kuvailevien viittomien ympärille tai on ei-leksikaalisista viittomista koostuva lauseaihio, jonka rakenne on vakiintuneen syntaksin lauseisiin nähden löyhä ja varioiva (ks. Jantunen, 2017a).

Erittäin tärkeä muuttuja vakiintuneen syntaksin ja vapaan syntaksin määritelmällisessä erottamisessa on konstruoitu toiminta. Konstruoidulla toiminnalla tarkoitetaan elepohjaista näyttelemistä, jota viittojat käyttävät diskurssissa näyttääkseen (engl. show; vrt. kertoakseen, engl. tell) puheenaiheena olevan referentin toimintaa, tunteita, ajatuksia ja sanomisia (Cormier ym., 2015; Ferrara \& Johnston, 2014; Hodge \& Ferrara, 2013; Jantunen, 2017a). Vakiintuneessa syntaksissa prototyyppinen lause ei sisällä lainkaan konstruoitua toimintaa. Sen sijaan vapaan syntaksin lauseissa konstruoidun toiminnan käyttö on hyvin yleistä, ja konstruoitua toimintaa voidaan jopa käyttää ilmaisemaan haluttu viesti lauseiden asemesta. ${ }^{3}$

Jatkumoajattelun mukaisesti konstruoitu toiminta voidaan toteuttaa eriasteisesti, ja uusimmassa tutkimuksessa (Cormier ym., 2015) konstruoitu toiminta onkin jaettu artikulatorisesti kolmeen alatyyppiin eli asteeseen: vahvaan, osittaiseen ja heikkoon konstruoituun toimintaan. Näitä konstruoidun toiminnan (proto)tyyppejä on havainnollistettu suomalaisen viittomakielen osalta kuviossa 6.

Cormierin ym. (2015) mukaan vahvan konstruoidun toiminnan ominaispiirre on, että puheena olevan hahmon toimintaa

3 Tässä konstruoituna toimintana (engl. constructed action) esitelty ilmiö on viittomakielten tutkimuksen historiassa tunnettu myös monilla muilla nimillä, joista kiistatta yleisin on ollut roolinvaihto (engl. role shift). Termiä roolinvaihto käytetään yhä etenkin formaaliin viitekehykseen sidotussa tutkimuksessa, jossa se tarkoittaa kieliopillista mekanismia, jolla viittojat siirtyvät puheena olevan hahmon rooliin ja välittävät informaatiota tämän hahmon näkökulmasta (esim. Lillo-Martin, 2012). Konstruoitu toiminta -termi perustuu idealle, että näytetty toiminta ei ole suoraa kopiota minkään hahmon toiminnasta, vaan pelkästään viittojan konstruoima (eri asteinen) aproksimaatio tästä toiminnasta (Metzger, 1995). Konstruoidusta toiminnasta on toisinaan erotettu konstruoitu dialogi (engl. constructed dialogue) eli 'sanomisen näyttäminen', mutta Cormierin ym. (2015) perusteella näin ei toimita tässä artikkelissa. 
Kuvio 6. Esimerkki vahvasta, osittaisesta ja heikosta konstruoidusta toiminnasta tarinassa, jossa viittoja kertoo pojan ja lumiukon talvisesta seikkailusta. Vahvassa asteessa (vasemmalla) viittoja on kokonaan lumiukon roolissa ja kaikki viittojan toiminta edustaa lumiukon toimintaa, käytännössä lumiukon kavahtamista säikähtäneenä taaksepäin. Osittaisessa asteessa (keskellä) viittoja tuottaa osittain leksikaalisen viittoman KATSOA, jonka yhteydessä viittojan pää, silmät ja ylävartalo ilmaisevat puheenaiheena olevaan poikaan liitettäviä ominaisuuksia. Heikossa asteessa (oikealla) viittoja näyttää pojan toimintaa ainoastaan silmillä, jotka avautuvat samanaikaisesti ja lievän korostuneesti leksikaalisen viittoman HERÄTÄ kanssa.
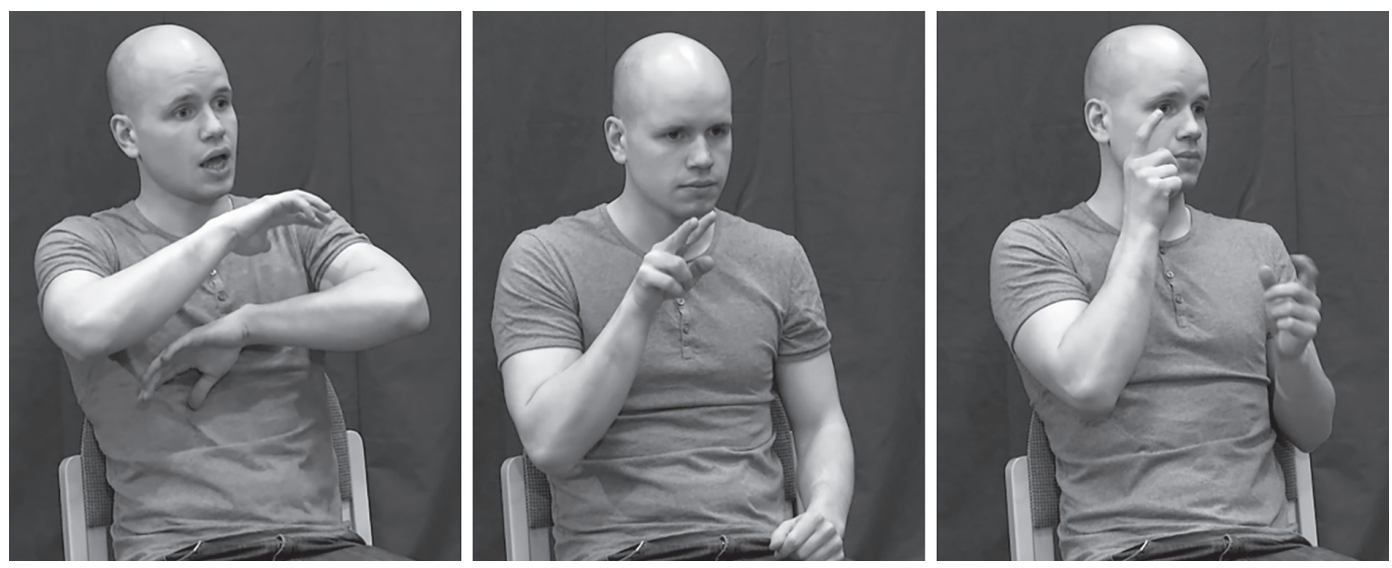

koodataan samanaikaisesti useammalla artikulaattorilla (kuvion 6 esimerkissä tämä tarkoittaa käytännössä kaikkia kuviteltavissa olevia artikulaattoreita). Vahvassa asteessa konstruoidun toiminnan ominaispiirteitä on niin ikään se, että käsillä ei tuoteta lainkaan kerrontaa edentäviä leksikaalisempia viittomia. Ylipäätään leksikaalisten viittomien tuottaminen vahvassa konstruoidussa toiminnassa on harvinaista, ellei tarkoitus sitten ole esittää hahmon puhetta viittoen. Osittaisessa konstruoidussa toiminnassa hahmon toimintaa koodaavien artikulaattoreiden määrä on vähäisempi kuin vahvassa asteessa, mutta suurempi kuin heikossa asteessa (ks. kuvio 6 , jossa osittaista konstruoitua toimintaa koodaavina artikulaattoreina toimivat ensisijaisesti pää, silmät ja yläruumis; dominoiva käsi ei ole konstruoitua toimintaa koodaava artikulaattori, sillä se tuottaa osoittavan viittoman KATSOA). Osittaisen konstruoidun toiminnan kanssa voidaan käyttää kerrontaa edentäviä leksikaalisempia viittomia. Heikossa konstruoidussa toiminnassa hahmoa koodataan tavallisesti vain yhdellä tai kahdella artikulaattorilla (kuvion 6 esimerkissä tämä tarkoittaa käytännössä vain silmiä). Heikko konstruoitu toiminta on yleensä kytkeytynyt hyvin hienovaraisesti muuhun kerrontaa edentävään vakiintuneen syntaksin ainekseen.

Pelkästään viittomiston näkökulmasta on osoitettu, että konstruoitu toiminta suosii vahvimmissa asteissaan osittain leksikaalisten ja ei-leksikaalisten viittomien käyttöä (De Beuzeville ym., 2009; Fenlon ym., 2018; Jantunen, 2017a). Verbaalikategoriaan kuuluvien osoittavien viittomien osalta on lisäksi näytetty toteen väite, että niiden osoituspotentiaalia pyritään hyödyntämään maksimaalisesti juuri konstruoidun toiminnan yhteydessä (De Beuzeville ym., 2009; Fenlon ym., 2018).

Konstruoitu toiminta on optionaalinen 
diskurssinrakentamisstrategia ja viittojat käyttävät sitä hyvin eri tavoin. Auslanista ja suomalaisesta viittomakielestä tehtyjen, kuvaileviin narratiiveihin pohjaavien korpustutkimusten perusteella konstruoidun toiminnan esiintymiskeskiarvo kerronnassa on vajaat 40-prosenttia (Ferrara \& Johnston, 2014; Jantunen, 2017a), mutta viittojakohtaisesti konstruoidun toiminnan käyttö vaihtelee 10-80-prosentin välillä (so. toiset viittojat eivät käytä konstruoitua toimintaa juuri lainkaan, kun taas toiset käyttävät sitä hyvin runsaasti). Uusimman suomalaisesta viittomakielestä tehdyn tutkimuksen myötä on pystytty arvioimaan myös konstruoidun toiminnan alatyyppien (vahvan, osittaisen ja heikon asteen) esiintyvyyttä kuvailevissa narratiiveissa. Kuuden viittojan tuottaman, yhteensä kolmenkymmenen lyhyen tarinan aineistossa vahvan konstruoidun toiminnan osuus oli 41-prosenttia, osittaisen 37-prosenttia ja heikon 22-prosenttia. Viittojakohtainen variaatio asteiden käytössä oli suurta, osan viittojien suosiessa vahvaa astetta, osan osittaista ja osan heikkoa. Kuvio 7 esittää pinottuna pylväskaaviona aineiston viittojakohtaiset keskiarvot vahvan, osittaisen ja heikon konstruoidun toiminnan sekä ilman konstruoitua toimintaa tuotetun viittomisen osalta.

Tiedossa on, että konstruoitua toimintaa ja sen alatyyppejä käytetään keskimääräisesti eri tavoin eri kohdissa kerrontaa. Tarinat pyritään aloittamaan ilman konstruoitua toimintaa (esim. Hodge \& Ferrara, 2013), ja tarinoiden ensimmäiset konstruoidun toiminnan jaksot eivät tyypillisesti edusta vahvaa astetta:

Kuvio 7. Vahvan, osittaisen ja heikon konstruoidun toiminnan sekä ilman konstruoitua toimintaa tuotetun kerronnan viittojakohtaiset keskiarvot kuvailevissa suomalaisen viittomakielen narratiiveissa. Aineisto on kerätty liikekaappauslaboratoriossa kuudelta viittojalta, joista jokainen tuotti viisi tarinaa. Tarinat perustuivat lyhyisiin tekstittömiin sarjakuvastrippeihin: viittojat valitsivat kymmenen stripin joukosta viisi itselleen mieluisinta ja viittoivat ne seisaaltaan edessään seisovalle keskustelukumppanille. Keskiarvot on laskettu annotointisolujen keston perusteella. Tarinoiden yhteiskesto on noin 20 minuuttia.

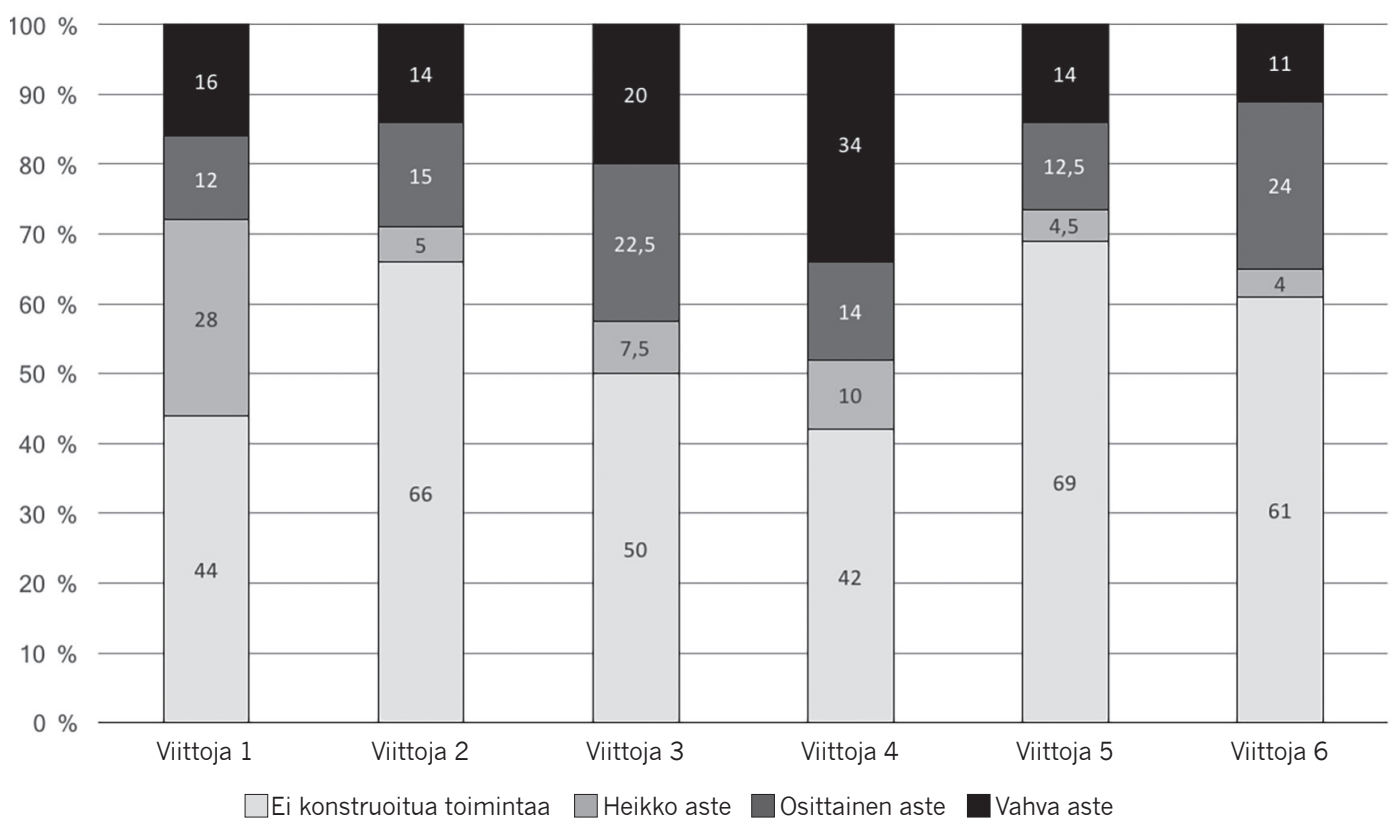


syy tähän on pyrkimys luoda ja vakiinnuttaa heti kerronnan alussa tarinassa mukana olevien hahmojen identiteetit ja viittaussuhteet, mikä onnistuu parhaiten leksikaalisia viittomia ja muita vakiintuneen syntaksin konventioita käyttäen. Tarinan edetessä hahmoihin voidaan sitten viitata helpommin - ja jopa pelkästään - vahvalla konstruoidulla toiminnalla (Cormier, Smith \& Zwets, 2013), jonka käyttö näin myös luo tarinaan omanlaistaan koheesiota (ks. Jantunen, 2017a). Tarinoiden lopussa konstruoidun toiminnan käyttöä jälleen vältetään.

Tiedossa on myös, että tekstilaji vaikuttaa suuresti konstruoidun toiminnan ja sen asteiden esiintymiseen. Kun tekstilaji vaihtuu yllä kuvatusta kuvailevasta narratiivista vapaammaksi keskusteluksi, laskee konstruoidun toiminnan osuus viittomisessa huomattavasti. Toisaalta on niin, että tekstilajin muuttuminen tällä tavoin muuttaa myös syitä, joiden vuoksi konstruoitua toimintaa käytetään: vapaammassa keskustelussa konstruoidulla toiminnalla ilmaistaan enemmän puheenaiheena olevien hahmojen sanomisia ja ajatuksia kuin toimintaa sinänsä. Tarkkoja frekvenssejä konstruoidun toiminnan käytön eroista eri tekstilajien välillä ei toistaiseksi ole saatavilla mistään viittomakielestä.

Konstruoidun toiminnan mukanaolo viittomakielisen viestin rakentumisessa vaikuttaa tapaan, jolla syntaktiset rakenteet ilmenevät. Kun ilman konstruoitua toimintaa tuotetut lauseet pyrkivät olemaan rakenteellisesti mahdollisimman täydellisiä ja esimerkiksi yhdistymään toisiinsa myös hierarkkisesti, niin konstruoidun toiminnan kanssa tuotetut lauseet ovat usein rakenteeltaan vajaita, ja yhdistyvät toisiinsa lähinnä vain lineaarisesti (Jantunen, 2017a).

Lauseiden rakenteellisessa vajaudessa on kyse ydinargumenttien omissiona eli poisjättönä tunnetusta elliptisestä ilmiöstä. Konstruoitu toiminta on vahva motivaattori tälle ilmiölle (De Beuzeville ym., 2009; Jantunen, 2013), joka suomalaisessakin viittomakielessä on hyvin yleinen: tarkan lauserakennetarkastelun (Jantunen, 2017b) perusteella on esimerkiksi laskettu, että 64-prosenttia intransitiivisista ja 85-prosenttia transitiivisista leksikaalisen tai osoittavan verbaalipredikaatin ympärille rakentuvista suomalaisen viittomakielen lauseista ilmenee (lausetyypistä riippuen) ilman ainoaa, toista tai molempia ydinargumentteja.

Konstruoidun toiminnan käyttö tekee mahdolliseksi sen, että lauseen kuvaaman tilanteen referenssisuhteet ja tieto osallistujista säilyy tulkittavana puuttuvista ydinargumenteista huolimatta. Tätä on havainnollistettu Jantuselta (2017a) lainatussa kuviossa 8, joka esittää suomalaista viittomakieltä käyttävää viittojaa tuottamassa osittaista konstruoitua toimintaa yhdessä osoittavaan luokkaan kuuluvan verbaaliviittoman KATSOA kanssa. Konteksti tilanteelle on, että viittoja kertoo pojasta ja koirasta, jotka tuijottavat lattialla lasipurkissa olevaa sammakkoa. Lausetasolla viittoja on juuri tuottanut rakenteellisesti täydellisenä ilmenneen intransitiivilauseen (myös) koira istuu, johon hän on nyt rinnastamassa additiivisesti ('ja') transitiivilausetta poika ja koira katselevat sammakkoa (additiivinen rinnastaminen toteutetaan kahden lauseen jukstapositiona, ks. Jantunen, 2016). Transitiivilauseen toteutuminen täydellisenä edellyttäisi sekä A-argumentin ('poika ja koira') että P-argumentin ('sammakko') ilmaisua, mutta näitä puheenaiheena olevia hahmoja ei ole esimerkissä viittoma- ja lausetasolla mukana lainkaan. Sen sijaan transitiivilause koostuu ainoastaan kaksipaikkaisesta verbaalipredikaatista KATSOA, joka tunnusmerkkisesti, tekijän roolissa olevien osallistujien ('poika ja koira') lukumäärää korostaen, artikuloidaan kahdella kädellä. Lauseen merkityksen tulkintaa ydinargumentin poisjättö ei kuitenkaan vaikeuta, sillä verbaalin kanssa tuotet- 
tu konstruoitu toiminta yhdessä edeltävän kontekstin ja verbaalin muodon kanssa antaa selkeät vihjeet tilanteen osallistujista. Poikaa ja koiraa osoittava (A-argumentin normaalisti koodaama) tekijätieto käy ilmi viittojan kasvoista ja muusta keholla ilmaistusta hahmoja kuvaavasta toiminnasta verbaalin tuoton aikana. Sammakkoon viittaava (P-argumentin normaalisti koodaama) tieto ilmenee puolestaan viittojan katseen suunnasta sekä tavasta, jolla verbaali on suunnattu.

Viimeaikainen syntaktinen tutkimus (Jantunen, 2017a) on niin ikään osoittanut, että konstruoidun toiminnan vahvojen asteiden käyttö suosii lineaarisia lauseiden ja lauseaihioiden yhdistämisperiaatteita, käytännössä rinnastusta ja ketjutusta (suomalaisen viittomakielen lauseiden lineaarisesta yhdistämisestä ks. Jantunen, 2016). Hierarkkista lauseiden yhdistämistä (alisteisuutta ja upotuksia) esiintyy vakiintuneen syntaksin puolella säännönmukaisesti, mutta mitä pidemmälle vapaan syntaksin puolelle viittomisessa siirrytään, sitä hallitsevamman roolin lineaarinen lauseiden yhdistely saa. Erityisesti kuvailevista verbaaliviittomista muodostuvat lauseet (vrt. "tyypin 3" verbaalit, ks. Jantunen, 2010) voivat konstruoidun toiminnan yhteydessä ja yhteensitomina ketjuuntua pitkiksikin eri tilanteiden sekvenssejä kuvaaviksi lausejonoiksi: Jantusen (2017a) aineistossa pisin tällainen jono koostui kahdeksasta peräkkäisestä lauseesta.

Kuvio 9 sijoittaa tässä luvussa käsitellyt ilmiöt kategorisuus-konventionaalisuusjatkumolle samaan tapaan, kuin luvussa 2 käsitellyt viittomatyypit. Korostettakoon, että vaikka siirtymät jatkumolla näkyvät ideaalitapauksessa samansuuntaisina muutoksina kaikissa parametreissa (parametrit on esitetty lihavoituna kuvion keskellä), tämä ei ole välttämätöntä. Näin ollen esimerkiksi

Kuvio 8. Kuvakaappaus ELAN-ruudusta, jossa viittoja välittää osallistujatietoja osittaisen konstruoidun toiminnan avulla. Kuvan lähde Jantunen (2017a).

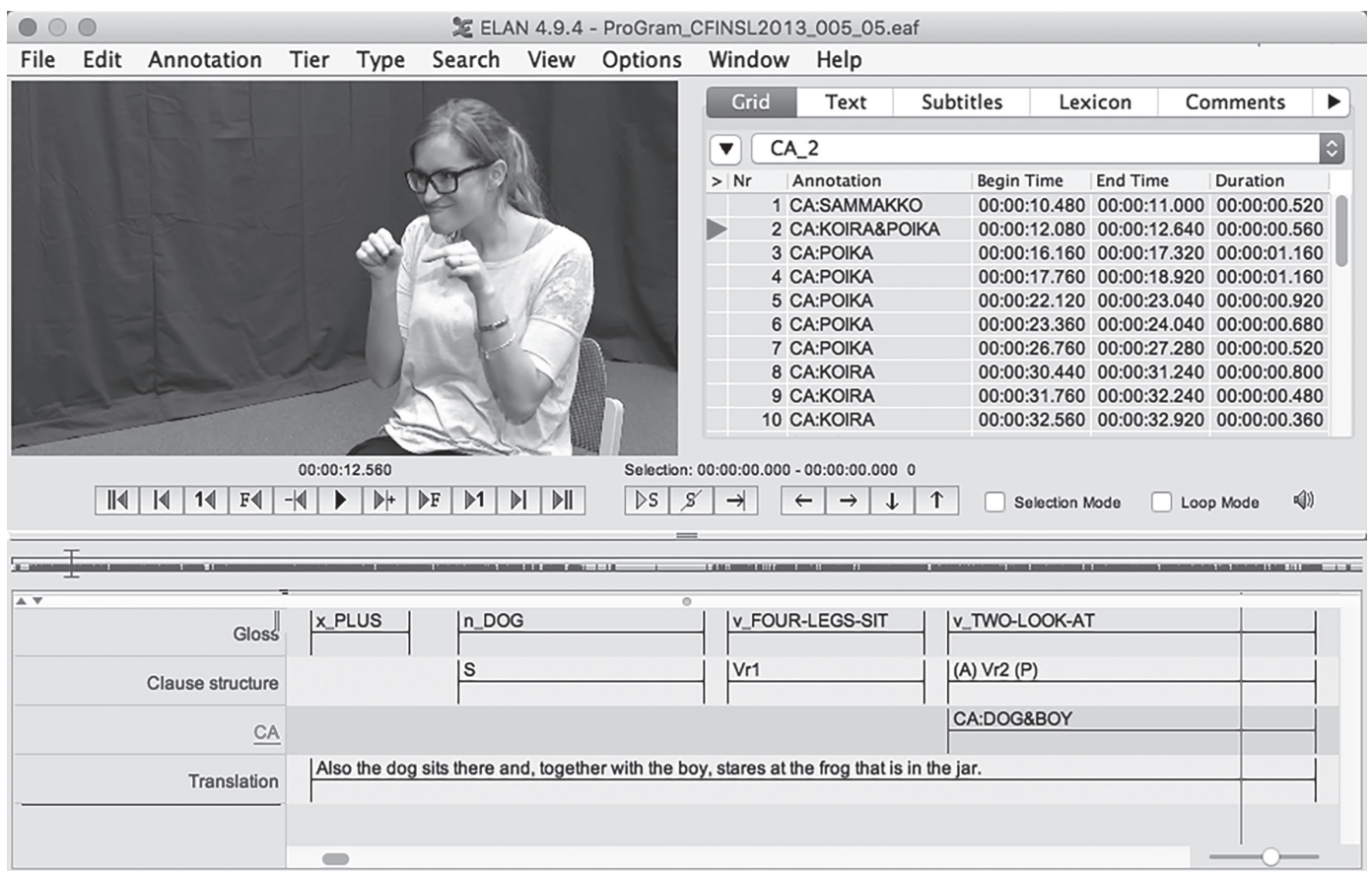


Kuvio 9. Konstruoitu toiminta ja joukko muita syntaktisia ilmiöitä kategorisuuskonventionaalisuus-jatkumolla.

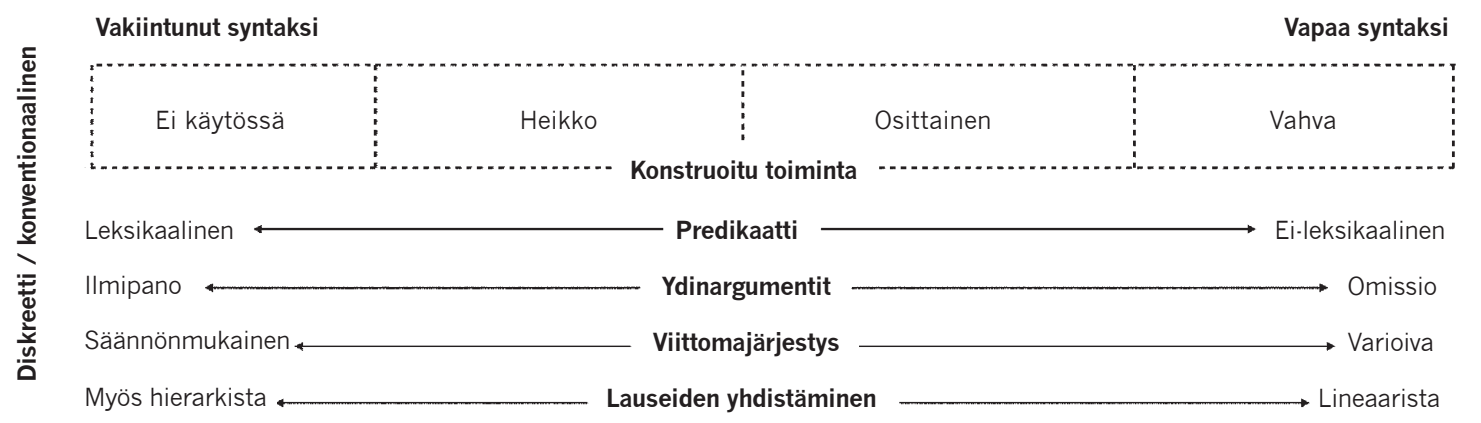

ydinargumentit voidaan jättää ilmipanematta myös heikossa konstruoidussa toiminnassa tai tavallisessa kerronnassa, tai jotain ei-leksikaalista viittomaa voidaan käyttää ilman konstruoitua toimintaa. Parametrien muuttumisen samanaikaisesti ja -suuntaisesti on osoitettu olevan tendenssi, mutta viime kädessä siinäkin on kyse yksittäisten viittojien tilannekohtaisesti tekemistä valinnoista.

Todettakoon myös, että hämärärajaisuudelle ja epäkonventionaalisuudelle perustuva vapaa syntaksi on haaste erityisesti viittomakielen opetukselle. Opetuksessa on perinteisesti painotettu - luonnollisesti tarkkarajaisuuteen ja konventionaalisuuteen vedoten - vakiintuneen syntaksin ilmiöitä, jotka mahdollistavat helpommin muun muassa oppimisen kannalta oleellisten säännönmukaisuuksien kodifioinnin ja muistinmerkinnän. Kielen kokonaisvaltaisen käytön kannalta on kuitenkin tärkeää, että kielenopiskelijat tutustuisivat tasapainoisesti myös vapaaseen syntaksiin ja oppisivat hallitsemaan tapoja, joilla muuttaa viittomista sen mukaan, missä kohtaa kategorisuus-konventionaalisuusjatkumoa he kulloinkin ovat. On tosin niin, että vapaan syntaksin periaatteiden pedagogisointi vaatii vielä lisää kielen rakenteen perustutkimusta.

\section{LOPUKSI - KOHTI HÄMÄRÄRAJAISUUTTA JA EPÄKONVENTIONAALISUUTTA PUHUTUISSA KIELISSÄ}

Edellä on esitetty, että viittomakielten leksikko ja syntaksi ovat diskreettien ja konventionaalisten sekä hämärärajaisten ja epäkonventionaalisten ominaisuuksien jatkumolle sijoittuvia olioita. ${ }^{4}$ Taustalla vaikuttaa ajatus, että myös kieli kokonaisuutena on käsitteellistettävissä tällaiselle jatkumolle sijoittuvaksi olioksi - eräänlaiseksi hybridisysteemiksi (ks. luku 1). Tämä tarkoittaa, että jatkumoajattelulle on löydettävä evidenssiä myös puhuttujen kielten puolelta.

Puhutuissa kielissä vaikuttavien hämärärajaisten ja epäkonventionaalisten - "eleisten" - ilmiöiden kattava käsittely ei ole tämän artikkelin tarkoitus. Yleisellä tasolla voidaan kuitenkin todeta, että myös puhuttuja kieliä

4 Käytännössä tämä artikkeli on rakentunut ajatukselle, että myös leksikko ja syntaksi muodostavat jatkumon (vrt. esim. leksikon ja syntaksin rajalle sijoittuvat osittain leksikaaliset kuvailevat viittomat, jotka ovat samalla lauseita). Ajatuksena tämä ei ole mitenkään uusi (ajatusta voidaan soveltaa myös kielen muiden perinteisten rakennetasojen välisiin suhteisiin), eikä sitä näin ole tekstissä mitenkään erikseen korostettu. 
on lähestytty tutkimuksissa yhä enenevässä määrin tässä artikkelissa tarkoitettuina hybridisysteemeinä. Leksikkoa tästä näkökulmasta käsitelleitä tutkijoita ovat muun muassa Dingemanse \& Akita (2016) ja Dingemanse (2018), jotka argumentoivat, että puhuttujen kielten onomatopoeettiset ilmaukset edustavat käytöltään puhuttujen kielten hämärärajaisempaa ja epäkonventionaalisempaa sanastoainesta. Käytännössä voidaan ajatella, että puhuttujen kielten onomatopoeettiset sanat ja ilmaukset vertautuisivat tässä artikkelissa esiteltyihin viittomakielten osittain leksikaalisiin ja ei-leksikaalisiin viittomiin (ks. luku 2). Osittain leksikkoon liittyvinä, puhuttujen kielten hämärärajaisuutta ja epäkonventionaalisuutta edustavina ilmiöinä voidaan pitää myös tiettyjä prosodisia keinoja, joilla muunnetaan sanojen muotoa vastaamaan puheena olevien ilmiöiden herättämiä mielikuvia. Esimerkki tällaisesta on löydettävissä vaikkapa ilmauksesta Matka sinne oli todella piiitkä (Jantunen \& Takkinen, 2011), jossa sanan pitkä ensimmäisen tavun vokaalin kestoa on pidennetty ikonisesti vastaamaan ja korostamaan mielikuvaa puheena olevan matkan pitkästä kestosta todellisuudessa (Okrent, 2002).

Esimerkkejä puhuttuja kieliä koskevista tutkimuksista, joissa on argumentoitu, että syntaksi - ja laajemmin kielioppi - sisältävät eleitä ja eleisyyttä - hämärärajaisuutta ja epäkonventionaalisuutta - ovat Floyd (2016) ja Ladewig (2014). Näistä Floyd on käsitellyt brasilialaisen alkuperäiskielen nheengatún tapaa viitata ajankohtiin vuorokauden sisällä. Tutkimuksessaan hän osoittaa, että näihin ajankohtiin on nheengatússa kehittynyt multimodaalisesti hybridi systeemi, joka sisältää paitsi äänellisesti tuotettua kieliopillista ainesta, myös taivaalle eri tavoin suunnatun osoituseleen käyttöä (ks. alaviite 1). Ladewig on puolestaan osoittanut, että esimerkiksi monet perinteisesti ellipsin aiheuttamiksi tulkitut syntaktiset aukot (engl.gaps) voidaan - ainakin kuvailevassa kerronnassa - täyttää puheeseen kytkeytyvällä näyttelemisellä ja eleillä. Esimerkkinä tästä Ladewig antaa pätkän tarinaa, jossa saksankielinen puhuja kertoo, kuinka sukulaiset työntävät tyttöä ikkunasta sisään. Tarina etenee puhutulla saksalla aina siihen saakka, kunnes puhuja tuottaa lauseen und wir hinten ('ja me takaapäin'), jonka lopussa subjektia wir ('me') ei seuraakaan työntämistä koodaava finiittiverbi vaan kaksikätinen ele, jolla kuvataan ihmisen työntämiseen tarkoitettua toimintaa (Ladewig, 2014: 1667). Käytännössä Ladewigin esimerkki on hyvin intuitiivisesti hyväksyttävä, ja ainakin osittain siinä on kyse vastaavasta ilmiöstä, johon tässä artikkelissa on viitattu konstruoituna toimintana ja sen asteina (ks. Jantunen, 2018).

Manuaalisten eleiden on osoitettu olevan saumattomasti yhteydessä puheeseen jo vuosikymmeniä sitten (esim. McNeil, 1992). McNeil (2000) on lisäksi esittänyt, että puheen kanssa samanaikaisesti ilmenevät manuaaliset eleet (so. elehtiminen, rytmiset eleet) olisivat suhteessa hyvin hämärärajaisia ja epäkonventionaalisia, kun taas itsenäisemmät (so. ilman puhetta ilmenevät) manuaaliset eleet (esim. metaforiset kuvailevat eleet) olisivat diskreetimpiä ja potentiaalisesti vahvastikin konventionaalisia. Jotkin puhujien käyttämät manuaaliset eleet, erityisesti kulttuurisidonnaiset embleemit (esim. peukku ylös, pystyssä oleva keskisormi), ovat jopa hyvin leksikaalisten viittomien kaltaisia, ja viime kädessä viittomakielten diskreetein ja konventionaalisin aines voidaankin nähdä näin muodostuvan manuaalisten eleiden jatkumon toisena ääripäänä. ${ }^{5}$

5 Leipätekstissä puheena oleva manuaalisten eleiden jatkumo on eletutkimuksen puolella hyvin kuuluisa ja se tunnetaan mm. nimellä Kendonin jatkumo (ks. Kendon, 2004). Siitä on olemassa useampia versioita, joista tässä on pohjana McNeilin (2000) esittämä tulkinta. 
Tiedossa siis on, että puhe on vain yksi (toki kiistatta keskeinen) resurssi puhujilla käytössä olevien semioottisten resurssien joukossa (esim. Enfield, 2009; Kendon, 2004; Streeck, Goodwin \& LeBaron, 2011 viitteineen). Näin ollen puhuttuakaan kieltä ei voida käsitteellistää pelkästään ääneen perustuvaksi, diskreettien kategorioiden ja vahvojen konventioiden järjestelmäksi (kuten on tehty perinteisessä autonomisessa kielitieteessä sekä esimerkiksi generativismissa), vaan tilaa on syytä antaa myös puhutun kielen tutkimuksessa hämärärajaisuuden ja epäkonventionaalisuuden jatkumoluonteisesti huomioon ottavalle hybridisysteemiajattelulle. Tässä artikkelissa tällaisen lähestymistavan on esitetty olevan toimiva ja käytetty vaihtoehto jo viittomakielten analyysissa.

Artikkelissa kuvattu tutkimus on rahoitettu Suomen Akatemian projekteista 269089, 273408 ja 304034.

\section{LÄHTEET}

Cormier, K., Smith, S. \& Sevcikva Sehyr, Z. (2015). Rethinking constructed action. Sign Language \& Linguistics, 18, 167-204.

Cormier, K., Smith, S. \& Zwets, M. (2013). Framing constructed action in British Sign Language narratives. Journal of Pragmatics, 55, 119-139.

De Beuzeville, L., Johnston, T. \& Schembri, A. (2009). The use of space with indicating verbs in Australian Sign Language: A corpus-based investigation. Sign Language \& Linguistics, 12, 52-83.

De Weerdt, D. (2008). Existential sentences in Flemish Sign Language and Finnish Sign Language. SKY Journal of Linguistics, 29, 7-38.

Dingemanse, M. \& Akita, K. (2016). An inverse relation between expressiveness and grammatical integration: On the morphosyntactic typology of ideophones, with special reference to Japanese. Journal of Linguistics, 53, 501-532. Dingemanse, M. (2018). Redrawing the margins of language: Lessons from research on ideophones. Glossa: A Journal of General Linguistics, 3, 1-30.

Enfield, N. (2009). The anatomy of meaning: Speech, gesture, and composite utterances. Cambridge: Cambridge University Press.

Fenlon, J., Schembri, A. \& Cormier, K. (2018). Modification of indicating verbs in British Sign Language: A corpus-based study. Language, 94, 84-118.

Ferrara, L. \& Johnston, T. (2014). Elaborating who's what: A study of constructed action and clause structure in Auslan (Australian Sign Language). Australian Journal of Linguistics, 34, 193-215.

Floyd, S. (2016). Modally hybrid grammar? Celestial pointing for time-of-day reference in Nheengatú. Language, 92, 31-64.

Hirn, D.F. (1910, 1911, 1916). De dövstummas àtbördsspråk i Finland - Kuuromykkäin viittomakieli Suomessa I-III. Finlands Dövstumförbunds Förlag, Helsingfors.

Hodge, G. \& Ferrara, L. (2013). Showing the story: Enactment as performance in Auslan narratives. Teoksessa L. Gawne \& J. Vaughan (toim.), Selected Papers from the 44th Conference of the Australian Linguistic Society, (s. 372-397). Melbourne: University of Melbourne.

Jantunen, T. (2003). Viittomien historiallinen muutos ja deikonisaatio suomalaisessa viittomakielessä. Puhe ja kieli, 23, 43-60.

Jantunen, T. (2008). Fixed and free: Order of the verbal predicate and its core arguments in declarative transitive clauses in Finnish Sign Language. SKY Journal of Linguistics, 21, 83-123.

Jantunen, T. (2010). Suomalaisen viittomakielen pääsanaluokat. Teoksessa T. Jantunen (toim.), Näkökulmia viittomaan ja viittomistoon, (s. 57-78). Jyväskylä: Jyväskylän yliopisto.

Jantunen, T. (2013). Ellipsis in Finnish Sign Language. Nordic Journal of Linguistics, 36, 303-332.

Jantunen, T. (2015). How long is the sign? Linguistics, 53, 93-124.

Jantunen, T. (2016). Clausal coordination in Finnish Sign Language. Studies in Language, 40, 204-234.

Jantunen, T. (2017a). Constructed action, the clause and the nature of syntax in Finnish Sign Language. Open Linguistics, 3, 65-85. 
Jantunen, T. (2017b). Fixed and NOT free: Revisiting the order of the main clausal constituents in Finnish Sign Language from a corpus perspective. SKY Journal of Linguistics, 30, 137-149.

Jantunen, T. (painossa). Elliptical phenomena in Finnish Sign Language. Teoksessa J. van Craenenbroeck \& T. Temmerman (toim.), The Oxford Handbook of Ellipsis. Oxford: Oxford University Press.

Jantunen, T., Pippuri, O., Wainio, T., Puupponen, A. \& Laaksonen, J. (2016). Annotated video corpus of FinSL with Kinect and computer-vision data. Teoksessa E. Efthimiou, F. StavroulaEvita, T. Hanke, J. Hochgesang, J. Kristoffersen \& J. Mesch (toim.), Proceedings of the 7th Workshop on the Representation and Processing of Sign Languages: Corpus Mining (s. 93-100). Paris: ELRA.

Jantunen, T. \& Takkinen, R. (2011). Puraistaan kieltä 4: Nyökkäys kohti kieltä. Puhe ja kieli, 31, 135 .

Johnston, T. \& Ferrara, L. (2012). Lexicalization in signed languages: When is an idiom not an idiom? Teoksessa G. Rundblad, A. Tytus, O. Knapton \& C. Tang (toim.), Selected Papers from UK-CLA Meetings, Vol 1, (s. 229-248). Saatavilla Internetissä: http://uk-cla.org.uk/ proceedings.

Johnston, T. (2017). Lexicalization and lexical frequency in Auslan. Ojenne Jyväskylän Yliopistossa järjestetyn luentosarjan ensimmäiseltä luennolta, 21.3.2017.

Kendon, A. (2004). Gesture: Visible action as utterance. Cambridge: Cambridge University Press.

Kendon, A. (2008). Some reflections on the relationship between 'gesture' and 'sign'. Gesture, 8, 348-366.

Keränen, J. (2017). Käsiotteelle ikoninen käsimuoto. Teoksessa R. Takkinen \& A. Puupponen (toim.), Maisteriksi viittomakielestä: 11 sukellusta suomalaiseen viittomakieleen, (s. 113-126). Jyväskylä: Jyväskylän yliopisto. Saatavilla Internetistä: http://urn.fi/ URN:ISBN:978-951-39-7189-2

Ladewig, S. (2014). Creating multimodal utterances: The linear integration of gestures into speech. Teoksessa Müller, Cienki, Fricke, Ladewig, McNeill, Bressem (toim.), Body-Language-Communication, (s. 1662-1677). Berlin:
De Gruyter.

Liddell, S.K. (2003). Grammar, gesture, andmeaning in American Sign Language. Cambridge: Cambridge University Press.

Lillo-Martin, D. (2012). Utterance reports and constructed action. Teoksessa R. Pfau, M. Steinbach \& B. Woll (toim.), Sign language: An international handbook, (s. 365-387). Berlin: De Gruyter Mouton.

McNeil, D. (1992). Hand and mind: What gestures reveal about thought. Chicago: University of Chicago Press.

McNeil, D. (2000). Language and gesture. Cambridge: Cambridge University Press.

Metzger, M. (1995). Constructed dialogue and constructed action in American Sign Language. Teoksessa C. Lucas (toim.), Sociolinguistics in deaf communities, (s. 255-271). Washington, DC: Gallaudet University Press.

Nichols, J. (1986). Head-marking and dependentmarking grammar. Language, 62, 56-119.

Okrent, A. (2002). A modality-free notion of gesture and how it can help us with the morpheme vs. gesture question in sign language linguistics (or at least give us some criteria to work with). Teoksessa R.P. Meier, K. Cormier \& D. QuintoPozos (toim.), Modality and structure in signed and spoken languages, (s. 175-198). Cambridge: Cambridge University Press.

Rissanen, T. (1998). The categories of nominals and verbals and their morphology in Finnish sign language. Licentiate thesis in general linguistics. The department of Finnish and general linguistics. University of Turku.

Salonen, J., Takkinen, R., Puupponen, A., Pippuri, O. \& Nieminen, H. (2016). Creating the corpus of Finland's sign languages. Teoksessa E. Efthimiou, F. Stavroula-Evita, T. Hanke, J. Hochgesang, J. Kristoffersen, J. Mesch (toim.), Proceedings of the 7th Workshop on the Representation and Processing of Sign Languages: Corpus Mining, (s. 179-185). Paris: ELRA.

Schembri, A. \& Johnston, T. (2017). Usage-based grammars and sign languages: Evidence from Auslan, BSL and NZSL. Julkaisematon käsikirjoitus. Saatavilla Internetissä: https://www.academia.edu/5244167

Streeck, J., Goodwin, C. \& LeBaron, C. (toim.) (2011). Embodied interaction: Language and body in the material world. Cambridge: Cam- 
bridge University Press.

Suomalaisen viittomakielen perussanakirjan (1998). Helsinki: KL-Support Oy.

Takkinen, R. (2008). Kuvailevat verbit suomalaisessa viittomakielessä. Puhe ja kieli, 28, 17-40.

Tapio, E. (2013). A nexus analysis of English in the everyday life of FinSL signers: A multimodal view on interaction. Väitöskirja. Oulu: Oulun vliopisto.
Van Valin, R. \& LaPolla, R. (1997). Syntax: Structure, meaning and function. Cambridge: Cambridge University Press.

Vermeerbergen, M. (2006). Past and current trends in sign language research. Language \& Communication, 26, 168-192.

Wilcox, S. \& Xavier, A.N. (2013). A framework for unifying spoken language, signed language and gesture. Revista Todas as Letras, 15. 88-110. 
SIGN LANGUAGES AS HYBRID SYSTEMS - GRADIENCE AND UNCONVENTIONALITY AS A PART OF THE STRUCTURE OF SIGN LANGUAGES

Tommi Jantunen, University of Jyväskylä, Department of Language and Communication Studies

This article investigates gradience and unconventionality as properties in the use of some units and structures found in all sign languages. Specifically, the article focuses on certain signs which have a contextually variable form and meaning (i.e. partly lexical signs), as well as on a type of gradual enactment (i.e. constructed action) which signers use with, inbetween and instead of traditional syntactic structures. In practice, the article presents a theoretical view according to which both phenomena in focus are conceptualized as hybrids that result from the mixing of discrete and conventional features of language with gradient and unconventional ones. Also, the nature of spoken languages as hybrid systems is briefly discussed.

Keywords: Finnish Sign Language, gesture, gradience, linguistic system, sign language, unconventionality 